\title{
On the Development Standard of Communist Party Members in Colleges and Universities
}

\author{
Pan Yihui ${ }^{1, a}$, Tu Keqin ${ }^{2, b}$,Wang Guangqing ${ }^{1, c}$ \\ ${ }^{1}$ Jiangxi Science \& Technology Normal University, Nanchang, Jiangxi, 330013, China \\ ${ }^{2}$ Nanchang Taohua School, Nanchang, Jiangxi, 330013, China \\ a35937488@qq.com, b610585086@qq.com, ${ }^{\mathrm{C}}$ wanggq005@163.com
}

Keywords: College students; Communist Party members standards; development strategy

\begin{abstract}
Communist Party members are the major colleges and universities for the community selection of talents standards, the standards of Communist Party members should strictly abide by Xi Jinping mentioned 20 standard, but nowadays, many colleges and universities on the requirements of the standard Communist Party members and evaluation of uneven, even many Colleges and universities as long as the students and teachers do a good job can be a Communist Party members, then what is the standard Communist Party at all words, so with the social changes, China's Communist Party standards are getting higher and higher, and articles from qualified conditions And the status quo of the development of Communist Party members in colleges and universities, and then put forward the corresponding standard of development of college students' Communist Party members according to the 20 standard proposed by Xi Jinping.
\end{abstract}

\section{Introduction}

Development and training of Communist Party members have always been the topic of concern in China, but with the development trend of society, more and more colleges and universities teachers in the selection of Communist Party members to cultivate, pay more attention to the relationship between teachers and the situation The It is like, do not flatter the students, even if there are more outstanding teachers are just one eye close one eye; can speak students, even if the overall quality, but off, as long as the teacher is obediently in front of students, teachers will recommend its For the Communist Party members. However, the article puts forward the strategy of developing the standards of the development of the standards of the Communist Party members of the university students on the conditions of the qualified Communist Party members and the present situation of the development of the Communist Party members in colleges and universities.

\section{Qualified conditions of qualified Communist party members}

As a member of the party, the Communist Party members are members of the political party, agree with all the programs of our party, abide by the party rules and voluntarily join the members, and qualified members of the Communist Party members need to meet three points, first of all need to know the historical development of the party to China's historical development for the identification To understand the development of China's rise and fall, and the party history is the fundamental of our country, as a qualified party members of the first step; the second is to understand our party situation, the party includes the number of Communist Party members, and under the pressure of anti-corruption need to face Of the "four big test" and "four major dangers", and want to do a qualified Communist Party members, the most important conditions are party spirit, the so-called party spirit is the chairman of the Communist Party of the 20-character standard , For the people, diligent and pragmatic, dare to play, clean and honest 


\section{The Current Situation of the Development of College Student Party Members}

Now the development of Communist Party members in colleges and universities more and more attention, first of all in the selection of party members pay more attention to student achievement, in the school teachers, it seems that only good grades can be better than everything, and then only focus on students from the election Communist Party members, ignoring the standards of the Communist Party members, the standard of the Communist Party members value more is the character of the people, so not only good students can be competent, colleges and universities in the development of Communist Party members ignored the standard Focus on academic performance, ignoring the development of character. Second, the relationship is that the university teachers receive a lot of gifts, students in the good performance and will speak the case, the teacher and then receive gifts, and then in the development of the Communist Party will be more time for the gift of students Good words, for this point in recent years, although not so blatantly, but still more or less the phenomenon of existence, which for those families in general students, is a fatal blow, and then to combat the enthusiasm of students to choose the Communist Party members, at the same time Think of the "gift" students of the character, today dare to send "small ceremony", tomorrow will not "send gift". So, now the development of Communist Party members in colleges and universities, need to focus on the comprehensive training of Communist Party members, improve the quality of Communist Party members

\section{According to the Chairman Xi's 20 - word standard, put forward the development strategy of college student Communist Party members}

\subsection{Beliefs firm, the establishment of training standards}

Learning the president of the 20 word standard, the first is the firm conviction, the so-called faith firm, that is to say the party's standard as the first creed, adhere to the "revolutionary ideals higher than the days of" faith, always for the realization of China's " And struggle, can not have two days fishing, three days sun network phenomenon, so in order to make the firm's beliefs firm, teachers need to arrange some training for students often. For example, the development of standards for the development of Communist Party members, in setting the development of Communist Party standards, the first need to proceed from several aspects, one is whether students are concerned about the performance of major political events, such as the recent very fire " "Events, you can see whether the students are concerned about what the idea of this event, the other training standards, but also for the students' ideological quality, work enthusiasm, spiritual aspects of training, through the establishment of training standards, And thus improve the enthusiasm of students to join the party, cultivate a firm standard of student beliefs.

\subsection{For the people to serve, severely punish the overall quality of students}

Service for the people has always been the purpose of the Communist Party members, so the overall quality of students is the need for elegant direction, not because of poor academic performance that the overall quality of students not work, which is the greatest bias on the students, but also weaken the enthusiasm of students to join the party Of the means, like a person did not offer a blood, you say he is not the same kind of truth, so when the Communist Party members in the development of standards set, the need to focus on the overall quality of the students, because only the "people Hope, the heart of the ", to the people's vision for the direction of governance, to make the hearts of the masses to a so, so that the service is the core of the development standards of the Communist Party members, so the development of standards for the development of Communist Party Of the time, the need to consider the overall quality of the students, for those who give gifts to the students, once the school found or other students anonymous report, verified that the case of the matter, should be punished accordingly, Through the severely punished students with low quality, training students to serve the people of the standard 


\subsection{Diligent and pragmatic, the implementation of all-round supervision}

Diligent and pragmatic is the standard of the third four words in the standard, which means in accordance with the normal rules of doing things, not fraud, the real goal of their own implementation, not through any means of destruction of others. For example, colleges and universities can be in the development of Communist Party members, everyone can arrange supervision power, that is between teachers and students, between life and life can be supervised, teachers, students to conduct a comprehensive supervision between students and students But in order to avoid supervision is not fair, you can let the students conduct a two-two groups to monitor, and in the group supervision, the teacher to master the personality of each student, and the group to achieve a comprehensive quality flat, and then And then supervise, so that students really understand the diligent and pragmatic attitude, and from the selection of the best students as the development potential of communists. At the same time, diligent and pragmatic, is a work attitude, teachers can also through some political cases, instilling students the correct diligent and pragmatic concept, training students diligent and pragmatic standards of Communist Party members.

\subsection{Dare to play, the role of change to cultivate attitude}

Dare to play is the twentieth standard in the second standard, but also with the last one of the standard play a complementary effect, dare to play is to explain a person with the sense of responsibility, there is a sense of responsibility, can make a big business, and a qualified Of the Communist Party members should have to tell the truth, talk about the principle, dare to face the problem, dare to assume the responsibility of the attitude, so the courage to play the attitude of students should have the development standards of the Communist Party members, and the role of conversion can see whether students have the courage to play Attitude. For example, according to some recent news cases, such as "Now a company does not go on, the company fired employees, but not enough funds to capitalize, the company leaders ran a similar case, asked the students" "And ask" what if you are, what do you do? "Observe the student's response, as well as the student's answer, develop the attitude of the student dare to play

\subsection{Clean and honest, by voting to win the winner}

The last Communist Party to develop standards, but also the most important of a standard is clean and honest, clean and honest is now the most lack of social standards of the Communist Party, because now the Communist Party members of the sleeves breeze very few, and talk about what services, so In the development of standard strategies for college student members of the Communist Party of China, more should be considered is to develop students clean and honest standards, in this training, the most effective way is to vote, college students are not primary school students do not assert, their three Has been gradually formed, so there is a certain understanding of right and wrong, so the vote is to reflect the students clean and honest attitude, such as singing competition, students vote, do not need to limit their own class, to see how students will vote, and then Choose the most fair voting students to develop the standard of development of Communist Party members.

\section{Summary}

In short, the standard of development of Communist Party members should be based on the 20-character standard proposed by the President, and then develop the standards for the development of students 'Communist Party members, raise the students' awareness of the development of the Communist Party members and the enthusiasm of the students to join the party. Firm, for the people, diligent and pragmatic, dare to play as well as clean and honest five members of the development standards.

This paper is the 2016 annual Jiangxi Provincial Party Building Research Project (planning general project): college student party members development standard strategy research (No. 16DJYB073) results. 


\section{References}

[1] Kou Yali. College students Communist Party members development quality [D]. Sichuan Agricultural University, 2016.

[2] Lu Canli, Zhou Rongwei.Improve the development of the object assessment mechanism to improve the quality of development of the Communist Party [J]. Theoretical observation, 2016,05: 34-35.

[3] Huang Yan. College to improve the quality of student members of the way research [J]. Decision to explore (the second half), 2016,06: 45.

[4] Li Haixia. College students Communist Party members quality control system construction [J]. Heilongjiang Education (Higher Education Research and Evaluation), 2015,02: 89-90.

[5] Guo Kai, Tang Wei.Study on the Strategy of Improving the Development Quality of College Student Party Members [J]. Theories, 2015, 20: 68-69. 